\title{
IL28B, HCV core mutations, and hepatocellular carcinoma: does host genetic make-up shape viral evolution in response to immunity?
}

\author{
Luca Valenti · Edoardo Pulixi · Susanna La Spina
}

Received: 28 September 2011 / Accepted: 19 November 2011/Published online: 7 December 2011

(C) Asian Pacific Association for the Study of the Liver 2011

\begin{abstract}
Mutations in the core sequence of the HCV genome have been reported to influence treatment response, fibrosis progression, and hepatocarcinogenesis in Asian patients with genotype-1 chronic hepatitis $\mathrm{C}(\mathrm{CHC})$. In this issue, Miura et al. report data consistent with a causal relationship between the $\mathrm{R} 70 \rightarrow \mathrm{Q} 70$ core variant and hepatocellular carcinoma (HCC) risk in CHC genotype-1b patients, by the prospective evaluation of changes in the consensus sequence in the entire open reading frame between treatment failure and HCC development or end of follow-up, and validation of the initial findings in a confirmatory cohort. Furthermore, they observed an association between the IL28B genotype, which is believed to influence the immune response to viral infection, and the direction of time-dependent changes in core residue 70 , with unfavorable $I L 28 B$ genotypes linked to a preferential shift to the 70Q associated with HCC. Although this association needs to be validated in independent cohorts, and $I L 28 B$ variants did not influence HCC risk, these results suggest that $I L 28 B$ genotype might not only influence the behavior of the innate immune system in the presence of HCV genotype-1 infection but also shape the resultant viral evolution, with possible consequences on major clinical outcomes, such as HCC development, and treatment response.
\end{abstract}

L. Valenti $(\bowtie) \cdot$ E. Pulixi $\cdot$ S. La Spina

Department of Internal Medicine, Centro Malattie Metaboliche del Fegato, Università degli Studi di Milano, Fondazione Ca' Granda IRCCS, Ospedale Maggiore Policlinico, Padiglione Granelli, Via F Sforza 35, 20122 Milan, Italy e-mail: luca.valenti@unimi.it
Keywords IL28B - Chronic hepatitis C - Hepatocellular carcinoma . Core mutations - Hepatitis $\mathrm{C}$ virus genome Steatosis · Interferon lambda

Chronic hepatitis $\mathrm{C}$ (CHC) affects roughly 170 million people worldwide and is a leading cause of cirrhosis and hepatocellular carcinoma (HCC), but its clinical course is highly variable, ranging from persistently inactive infection to rapidly progressing aggressive hepatitis. Therefore, considerable research effort has been devoted to understand the causes of such heterogeneity in disease evolution.

Inherited host factors influence fibrogenesis in $\mathrm{CHC}$ patients [1], often by interacting with acquired risk factors, as exemplified by the synergic effect of overweight, alcohol, and the PNPLA3 I148M polymorphism in the pathogenesis of steatosis, a major cofactor of liver damage in CHC [2-5]. Besides conditioning treatment response, viral factors also impact on disease evolution, and again the directly steatogenic HCV genotype-3 has been linked to accelerated fibrosis [6].

The HCV core protein is implicated in disease pathogenesis, influencing several cellular pathways, including oxidative stress, cell proliferation, and steatosis, and exhibiting oncogenic potential in transgenic models [7]. Among other regions of the HCV genome, variations in the core sequence have been linked to disease progression and $\mathrm{HCC}$ risk in patients affected by genotype- $1 \mathrm{HCV}$, which is the most common and difficult to cure viral strain. Amino acid substitutions at positions 70 and 91 of the core protein have been associated with treatment failure in Asian patients with $\mathrm{CHC}$ genotype- $1 \mathrm{~b}$ treated with interferon and ribavirin [8], and with sustained viral response and viral dynamics during triple therapy with peginterferon, ribavirin, and the $\mathrm{HCV}$ protease inhibitor telaprevir [9]. 
Furthermore, mutations in the core sequence have been shown to influence HCC development in subjects with genotype $1 \mathrm{CHC}$ who did not respond to antiviral therapy and also in those who achieved viral eradication $[8,10,11]$.

In this issue of Hepatology International, Miura et al. [12] confirmed the association between the R70Q core variant and HCC risk by evaluating changes in the consensus sequence in the entire open reading frame of $\mathrm{CHC}$ genotype- $1 \mathrm{~b}$ in Asian patients between treatment failure and HCC development or end of follow-up, and by validating the initial findings in a confirmatory cohort. They found that $\mathrm{R} \rightarrow \mathrm{Q}$ changes at position 70 of the core sequence were frequently observed during follow-up in patients who developed HCC, so that the 70Q variant was significantly over-represented in affected patients compared to controls at the time of HCC development. In line with previous studies, patients with the 70Q variant showed also an accelerated decline in liver function indices. Although these results are not per se novel, the systematic unbiased evaluation of the entire open reading frame of $\mathrm{HCV}$ in prospectively followed patients who developed $\mathrm{HCC}$ and controls, and the validation of the associated mutations in an independent larger set of patients represent important strengths of this study. Most importantly, the authors went then on to analyze the relationship between viral features and the $I L 28 B$ genotype, a host genetic factor influencing the immune response against HCV.

Genome-wide association studies have recently identified genetic variations near the $I L 28 B$ gene, encoding for interferon (IFN)- $\lambda 3$, as a strong predictor of spontaneous and treatment-induced clearance of hepatitis C infection [13-18]. Protective variants at the rs12979860 and rs8099917 loci have consistently been associated with faster decline in viral load and an approximately twofold higher sustained virologic response rate during standard of care treatment, particularly, in patients affected by the difficult to cure HCV genotypes 1 and $4[19,20]$. The mechanism by which these genetic variants influence the outcome of $\mathrm{HCV}$ infection, i.e., whether they influence IFN- $\lambda 3$ expression by affecting gene transcription or are linked to a coding variant (Lys70Arg) of the IFN- $\lambda 3$ protein, is still debated [14, 18]. However, it is known that these variants result in a different pattern of activation of the innate immune system against $\mathrm{HCV}$ infection, as determined by the different basal and IFN- $\alpha$ induced expression of interferon-stimulated genes and inflammatory activity [21, 22]. Favorable IL28B variants, likely through the effect of inflammatory cytokines on lipid metabolism [23], protect against the development of steatosis [24] and possibly steatosis-associated fibrosis progression and increased HCC risk [2, 4]. As a result, $I L 28 B$ variants likely have no major effect on the fibrosis-progression rate in patients with ongoing HCV infection [6], even if evidence is still controversial [25]. Even scanty data are available on the possible role of $I L 28 B$ polymorphisms in determining the risk of $\mathrm{HCC}$, and although a higher prevalence of unfavorable genotypes has been reported in one series, results were not controlled for the outcome of antiviral therapies [25].

A novel finding reported by Miura et al. [12] consists of the association between $I L 28 B$ genotype and the direction of time-dependent changes in core residue 70 , with unfavorable rs8099917 genotypes linked to preferential shift to the 70Q. Although this association needs to be validated in independent cohorts of patients, as it was not reported in previous studies [9], these results suggest that the IL28B genotype might not only influence the behavior of the innate immune system in the presence of HCV genotype-1 infection but also shape the resultant viral evolution, with possible consequences on major clinical outcomes, such as HCC development. This raises the question of whether host genetic make-up shapes viral evolution in response to immunity, and whether the resultant differences in the evolution of HCV quasi-species are implicated in the mechanism by which the IL28B genotype influences the outcome of acute $\mathrm{HCV}$ infection and treatment response. These are two key questions that will be answered provided the results of Miura et al. [12] are replicated in independent studies.

Another interesting aspect that has not so far been addressed in the literature concerns the relationship between HCV core variants and hepatic steatosis. Indeed, promotion of liver fat accumulation and the resultant inflammation, altered iron metabolism/oxidative stress, and insulin resistance are involved in the hepatocarcinogenesis promoted by the HCV core [7, 26-28], but systematic data on the relationship between $\mathrm{HCV}$ core variants and steatosis are not available.

In the study of Miura et al. [12], the IL28B genotype did not influence HCC risk [12], suggesting that the relationship between core mutations and HCC is not straightforward, but other factors complicate the picture. It is tempting to speculate that the protection provided by unfavorable $I L 28 B$ genotypes against inflammation [24, 29] may compensate for the association with the $70 \mathrm{Q}$ core variant and explain the lack of influence on HCC, but further studies evaluating prospectively the interaction among genotypes of IL28B, PNPLA3 (associated with steatosis and HCC in CHC [4]), and HCV core mutants are needed to test this hypothesis.

In conclusion, the study by Miura et al. [12] confirms by an unbiased approach that variants of the core protein are risk factors for HCC in Asian patients with genotype-1 CHC. It also raises the possibility that the host genetic make-up, namely, the IL28B genotype, shapes viral evolution in response to the immune system, with possible 
implications for disease pathogenesis, resistance to antiviral therapy, and HCC risk. Further independent studies are warranted to validate these findings.

Conflict of interest There is no conflict of interest to disclose.

\section{References}

1. Trepo E, Potthoff A, Pradat P, Bakshi R, Young B, Lagier R, Moreno C, Verset L, Cross R, Degre D, Lemmers A, Gustot T, Berthillon P, Rosenberg W, Trepo C, Sninsky J, Adler M, Wedemeyer $\mathrm{H}$. Role of a cirrhosis risk score for the early prediction of fibrosis progression in hepatitis $\mathrm{C}$ patients with minimal liver disease. J Hepatol 2011;55:38-44

2. Leandro G, Mangia A, Hui J, Fabris P, Rubbia-Brandt L, Colloredo G, Adinolfi LE, Asselah T, Jonsson JR, Smedile A, Terrault N, Pazienza V, Giordani MT, Giostra E, Sonzogni A, Ruggiero G, Marcellin P, Powell EE, George J, Negro F. Relationship between steatosis, inflammation, and fibrosis in chronic hepatitis C: a meta-analysis of individual patient data. Gastroenterology 2006;130:1636-1642

3. Muller T, Buch S, Berg T, Hampe J, Stickel F. Distinct, alcoholmodulated effects of PNPLA3 genotype on progression of chronic hepatitis C. J Hepatol 2011;55:732-733

4. Valenti L, Rumi M, Galmozzi E, Aghemo A, Del Menico B, De Nicola S, Dongiovanni P, Maggioni M, Fracanzani AL, Rametta R, Colombo M, Fargion S. Patatin-like phospholipase domaincontaining 3 I148M polymorphism, steatosis, and liver damage in chronic hepatitis C. Hepatology 2011;53:791-799

5. Trepo E, Pradat P, Potthoff A, Momozawa Y, Quertinmont E, Gustot T, Lemmers A, Berthillon P, Amininejad L, Chevalier M, Deviere J, Manns M, Trepo C, Sninsky J, Wedemeyer H, Franchimont D, Moreno C. Impact of PNPLA3 (rs738409 C > G) polymorphism on fibrosis progression and steatosis in chronic hepatitis C. Hepatology 2011;54:60-69

6. Marabita F, Aghemo A, De Nicola S, Rumi MG, Cheroni C, Scavelli R, Crimi M, Soffredini R, Abrignani S, De Francesco R, Colombo M. Genetic variation in the interleukin-28B gene is not associated with fibrosis progression in patients with chronic hepatitis C and known date of infection. Hepatology 2011;54: 1127-1134

7. Moriya K, Fujie H, Shintani Y, Yotsuyanagi H, Tsutsumi T, Ishibashi K, Matsuura Y, Kimura S, Miyamura T, Koike K. The core protein of hepatitis $\mathrm{C}$ virus induces hepatocellular carcinoma in transgenic mice. Nat Med 1998;4:1065-1067

8. Akuta N, Suzuki F, Kawamura Y, Yatsuji H, Sezaki H, Suzuki Y, Hosaka T, Kobayashi M, Arase Y, Ikeda K, Kumada H. Amino acid substitutions in the hepatitis $\mathrm{C}$ virus core region are the important predictor of hepatocarcinogenesis. Hepatology 2007; 46:1357-1364

9. Akuta N, Suzuki F, Hirakawa M, Kawamura Y, Yatsuji H, Sezaki H, Suzuki Y, Hosaka T, Kobayashi M, Saitoh S, Arase Y, Ikeda K, Chayama K, Nakamura Y, Kumada H. Amino acid substitution in HCV core region and genetic variation near the IL28B gene affect viral dynamics during telaprevir, peginterferon and ribavirin treatment. Intervirology 2011 [Epub ahead of print]

10. Akuta N, Suzuki F, Hirakawa M, Kawamura Y, Sezaki H, Suzuki Y, Hosaka T, Kobayashi M, Saitoh S, Arase Y, Ikeda K, Kumada H. Amino acid substitutions in hepatitis $\mathrm{C}$ virus core region predict hepatocarcinogenesis following eradication of HCV RNA by antiviral therapy. J Med Virol 2011;83:1016-1022

11. Nakamoto S, Imazeki F, Fukai K, Fujiwara K, Arai M, Kanda T, Yonemitsu Y, Yokosuka O. Association between mutations in the core region of hepatitis $\mathrm{C}$ virus genotype 1 and hepatocellular carcinoma development. J Hepatol 2010;52:72-78

12. Miura M, Maekawa S, Kadokura M, Sueki R, Komase K, Shindo H, Ohmori T, Kanayama A, Shindo K, Amemiya F, Nakayama Y, Kitamura T, Uetake T, Inoue T, Sakamoto M, Okada S, Enomoto N. Analysis of viral amino acids sequences and the Il28B SNP influencing the development of hepatocellular carcinoma in chronic hepatitis C. Hepatol Int 2011 [Epub ahead of print]

13. Ge D, Fellay J, Thompson AJ, Simon JS, Shianna KV, Urban TJ, Heinzen EL, Qiu P, Bertelsen AH, Muir AJ, Sulkowski M, McHutchison JG, Goldstein DB. Genetic variation in IL28B predicts hepatitis $\mathrm{C}$ treatment-induced viral clearance. Nature 2009;461:399-401

14. Lange CM, Zeuzem S. IL28B single nucleotide polymorphisms in the treatment of hepatitis C. J Hepatol 2011;55:692-701

15. Thomas DL, Thio CL, Martin MP, Qi Y, Ge D, O'Huigin C, Kidd J, Kidd K, Khakoo SI, Alexander G, Goedert JJ, Kirk GD, Donfield SM, Rosen HR, Tobler LH, Busch MP, McHutchison JG, Goldstein DB, Carrington M. Genetic variation in IL28B and spontaneous clearance of hepatitis C virus. Nature 2009;461:798-801

16. Rauch A, Kutalik Z, Descombes P, Cai T, Di Iulio J, Mueller T, Bochud M, Battegay M, Bernasconi E, Borovicka J, Colombo S, Cerny A, Dufour JF, Furrer H, Gunthard HF, Heim M, Hirschel B, Malinverni R, Moradpour D, Mullhaupt B, Witteck A, Beckmann JS, Berg T, Bergmann S, Negro F, Telenti A, Bochud PY. Genetic variation in IL28B is associated with chronic hepatitis $\mathrm{C}$ and treatment failure: A genome-wide association study. Gastroenterology 2010;138:1338-1345, 1345 e1331-e1337

17. Suppiah V, Moldovan M, Ahlenstiel G, Berg T, Weltman M, Abate ML, Bassendine M, Spengler U, Dore GJ, Powell E, Riordan S, Sheridan D, Smedile A, Fragomeli V, Muller T, Bahlo M, Stewart GJ, Booth DR, George J. IL28B is associated with response to chronic hepatitis $\mathrm{C}$ interferon-alpha and ribavirin therapy. Nat Genet 2009;41:1100-1104

18. Tanaka Y, Nishida N, Sugiyama M, Kurosaki M, Matsuura K, Sakamoto N, Nakagawa M, Korenaga M, Hino K, Hige S, Ito Y, Mita E, Tanaka E, Mochida S, Murawaki Y, Honda M, Sakai A, Hiasa Y, Nishiguchi S, Koike A, Sakaida I, Imamura M, Ito K, Yano K, Masaki N, Sugauchi F, Izumi N, Tokunaga K, Mizokami M. Genome-wide association of IL28B with response to pegylated interferon-alpha and ribavirin therapy for chronic hepatitis C. Nat Genet 2009;41:1105-1109

19. Galmozzi E, Del Menico B, Rametta R, Dongiovanni $P$, Fracanzani A, Benedan L, Borroni V, Maggioni P, Fargion S, Valenti L. A tetra-primer amplification refractory mutation system polymerase chain reaction for the evalutation of rs 12979860 genotype. J Viral Hepat 2010;18:628-630

20. De Nicola S, Aghemo A, Rumi MG, Galmozzi E, Valenti L, Soffredini R, De Francesco R, Prati GM, D'Ambrosio R, Cheroni C, Donato MF, Colombo M. An IL28B polymorphism predicts pegylated interferon plus ribavirin treatment outcome in chronic hepatitis c genotype 4. Hepatology 2011. doi:10.1002/hep.24683

21. Honda M, Sakai A, Yamashita T, Nakamoto Y, Mizukoshi E, Sakai Y, Nakamura M, Shirasaki T, Horimoto K, Tanaka Y, Tokunaga K, Mizokami M, Kaneko S. Hepatic ISG expression is associated with genetic variation in interleukin $28 \mathrm{~B}$ and the outcome of IFN therapy for chronic hepatitis C. Gastroenterology 2010;139:499-509

22. Abe H, Ochi H, Maekawa T, Hayes CN, Tsuge M, Miki D, Mitsui F, Hiraga N, Imamura M, Takahashi S, Ohishi W, Arihiro K, Kubo M, Nakamura Y, Chayama K. A common variation of IL28 affects gamma-GTP levels and inflammation of the liver in chronically infected hepatitis $\mathrm{C}$ virus patients. J Hepatol 2010;53:439-443

23. Valenti L, Pulixi E, Fracanzani AL, Dongiovanni P, Maggioni M, Orsatti A, Gianni C, Fargion S. TNFalpha genotype affects 
TNFalpha release, insulin sensitivity and the severity of liver disease in HCV chronic hepatitis. J Hepatol 2005;43:944-950

24. Tillmann HL, Patel K, Muir AJ, Guy CD, Li JH, Lao XQ, Thompson A, Clark PJ, Gardner SD, McHutchison JG, McCarthy JJ. Beneficial IL28B genotype associated with lower frequency of hepatic steatosis in patients with chronic hepatitis C. J Hepatol 2011 [Epub ahead of print]

25. Fabris C, Falleti E, Cussigh A, Bitetto D, Fontanini E, Bignulin S, Cmet S, Fornasiere E, Fumolo E, Fangazio S, Cerutti A, Minisini R, Pirisi M, Toniutto P. IL-28B rs12979860 C/T allele distribution in patients with liver cirrhosis: Role in the course of chronic viral hepatitis and the development of HCC. J Hepatol 2011;54:716-722

26. Shintani Y, Fujie H, Miyoshi H, Tsutsumi T, Tsukamoto K, Kimura S, Moriya K, Koike K. Hepatitis $\mathrm{C}$ virus infection and diabetes: direct involvement of the virus in the development of insulin resistance. Gastroenterology 2004;126:840-848
27. Moriya K, Miyoshi H, Shinzawa S, Tsutsumi T, Fujie H, Goto K, Shintani Y, Yotsuyanagi H, Koike K. Hepatitis C virus core protein compromises iron-induced activation of antioxidants in mice and HepG2 cells. J Med Virol 2010;82:776-792

28. Valenti L, Pulixi EA, Arosio P, Cremonesi L, Biasiotto G, Dongiovanni P, Maggioni M, Fargion S, Fracanzani AL. Relative contribution of iron genes, dysmetabolism and hepatitis $\mathrm{C}$ virus $(\mathrm{HCV})$ in the pathogenesis of altered iron regulation in $\mathrm{HCV}$ chronic hepatitis. Haematologica 2007;92:1037-1042

29. Cai T, Dufour JF, Muellhaupt B, Gerlach T, Heim M, Moradpour D, Cerny A, Malinverni R, Kaddai V, Bochud M, Negro F, Bochud PY. Viral genotype-specific role of PNPLA3, PPARG, MTTP and IL28B in hepatitis C virus-associated steatosis. J Hepatol 2011;55:529-535 